\title{
Sub-Ethnic Identity and Conflict in Nigeria: The Policy Option for the Resolution of the Conflict between Ezza and Ezillo in Ebonyi State
}

\author{
Dr. Peter Mbah \\ Department of Political Science \\ University of Nigeria, Nsukka \\ ombah2006@yahoo.com \\ Mr. Chikodiri Nwangwu \\ Department of Political Science \\ University of Nigeria, Nsukka \\ amby4president@yahoo.com
}

\section{Doi:10.5901/mjss.2014.v5n2p681}

\begin{abstract}
Nigeria's high level of ethnic diversity can explain the country's ethnic based conflicts. Scholars have focused attention on explaining these inter-ethnic conflicts using political and linguistic differences as well as patterns of segregation as factors behind the conflicts. However, sub-ethnic identity conflicts are becoming increasingly common in Nigeria today. While such conflicts hardly attract academic attention relative to inter-ethnic conflict, they are capable of yielding theoretical insights into identity formation, ethnic transformation and the questions that border on citizenship. This study, therefore, analyzes the conflict between Ezza and Ezillo in Ebonyi State. It assesses the role of material interest and deep-seated animosity in the conflict between the two communities in a homogenous setting. It argues that the conflicts emanate from the interface between material interest and animosity. Our analysis indicates that the effects are deep-rooted and widespread. The study made use of documents and interviews as its method of data collection. It concludes that political factors, linguistic differences and patterns of ethnic segregation are found to be poor predictors of sub-ethnic identity conflict. It finally proffers a-people-oriented approach to conflict resolution.
\end{abstract}

Keywords: Sub-ethnic identity, ethnic conflict, material interest, animosity, Ezza-Ezillo

\section{Introduction}

The frequent manifestation of inter-ethnic violence in Nigeria has brought to the fore the issue of ethnicity and ethnic conflicts in Nigeria. The situation has become extremely worrisome since the inauguration of the Nigeria's Fourth Republic in 1999. The country has witnessed the outbreak of not less than forty violent communal or ethnic conflicts (Imobighe, 2003: 13). These conflicts are both inter and intra-ethnic in nature. Among the prominent recent ones are: Zango-Kataf in Kaduna State; Tiv-Jukun in Wukari, Taraba State; Ogoni-Adoni in Rivers State; Chamba-Kuteb in Taraba State; Itsekiri-ljaw/Urhobo in Delta State; Ife-Modakeke in Osun State; Aguleri-Umuleri in Anambra State; Yoruba-Hausa Community in Shagamu, Ogun State; ljaw-llaje conflict in Ondo State; the intermittent clashes in Kano, Kano State; Basa-Egbura in Nassarawa State; Eleme-Okrika in Rivers State; Hausa/Fulani-Sawaya in Bauch State (Imobighe, 2003: 13). These conflicts have become so pervasive that there is hardly any part of the country that has not witnessed one conflict or the other. These conflicts have implication for economic and political development in Nigeria.

In their pioneering article, Easterly and Levine (1997) suggested that Sub-Saharan Africa's high level of ethnic diversity can explain the regions poor economic performance. However, a leading set of explanations for the poor economic performance of ethnically diverse countries is political (Frank and Rainer, 2012: 294). It is often argued that ethnic diversity leads to costly rent-seeking by different ethnic groups and this generates ethnic conflict over the provision of public goods. These arguments imply that politically dominant ethnic groups will use their power to provide economic benefits to their own members (Frank and Rainer, 2012). In ethnically heterogeneous societies, it has been common for the groups that come to power to fashion government policies that expropriate the ethnic losers and limit the production of pubic goods to prevent those outside the ruling group from also benefiting and getting stronger (La Porta et al, 1999: 231). Consequently, ethnic favoritism becomes prominent theme in formal theories of ethnic politics. In most African 
countries, state power has become means of production for the ethnic group that has acquired it. It is used as an exclusion device, and the winning ethnic groups redistribute resources to their own members. These patterns above generate inter-ethnic conflicts that are widespread and multi-dimensional. Nigeria presents complex individuals and crisscross and recursive identities of which the ethnic, religious and sub-ethnic are the most salient and the main launch pad for violent conflicts in the country. In most cases ethnic and religious identities are most often reinforcing. The identities are often implicated in many contestations over citizenship/indigene competition and conflict over resources and privileges.

Ezza and Ezillo are two communities in Ebonyi State. They are both located in the Ishielu Local Government Area of the state. The state is ethnically homogenous, being one of the states in the Igbo heartland. Unlike many multi-ethnic communities in Nigeria, it seems reasonable to assume that identity based conflicts would be minimal in such a setting of ethnic homogeneity. To the contrary, Ezza and Ezillo have been engaged in an explosive struggle dating back to the beginning of the last century.

Micro-ethnic identity conflicts are becoming increasingly common in Nigeria. Apart from the Ezza-Ezillo conflict, the Aguleri-Umuleri and the Ife-Modakeke conflicts are also well-known. Apart from the above, there are other numerous and serious intra-ethnic conflicts that remain largely unreported, yet pose extremely serious threat in terms of loss of lives and destruction of livelihoods. In the South-East Zone of Nigeria alone, a study twelve years ago recorded over seventy serious conflicts among Igbo sub-identities (Ibeanu and Onu, 2001: 51). However, this number might have increased two-folds. The most important one is the Umu-Ode-Oruku conflict in Nkanu East Local Government Area of Enugu State. While such conflicts may not attract as much academic attention as macro-ethnic conflicts, they are capable of yielding theoretical insights into identity formation, ethnic transformations and questions of citizenship in a dynamic setting like Nigeria.

Sub-ethnic conflicts in Nigeria certainly predate colonialism. However, they have been shaped and sustained by the structure of the post-colonial State (Ibeanu and Mbah, 2011: 1). First, colonialism set the pace for modernization and economic development in Nigeria, while dramatically changing existing patterns of social, political and economic interactions of ethnic groups and communities. Second, colonialism had far reaching impact on ethnic group consciousness. Outside the gates, colonialism was conducive to the emergence of pan-ethnic identities, particularly in the competitive setting of urban areas (Nnoli, 1980). However, within the gates, colonialism encouraged micro-ethnic, often competitive identities. Within the Igbo ethnic group for instance, sub-ethnic identities such as Ado (the Onitsha Igbo), Wawa (the Northern Igbo of Enugu State), Jookwa (the Afikpo), Ohuhu (parts of Central Igbo land) and ljekebe (the old Onitsha colonial province) have emerged mainly from clans increasingly claiming a sub-ethnic identity. The foregoing should not be seen as a denial of the existence of sub-ethnic division among the Igbo prior to colonialism. In this study, we explore how in spite of a pan-Igbo identity, serious sub-ethnic identity conflicts have persisted. Using EzzaEzillo case, we hope to shed light on a layer of identity formation and the citizenship question in Nigeria that remains largely neglected. That is not to suggest that existing explanations are wrong, but we hope to bring a new explanatory framework to analyze the increasing sub-ethnic conflicts in Nigeria.

Nigeria today, is divided into six geo-political zones. One of the zones is the South-East zone. The South-East Zone of Nigeria comprises the five states of Abia, Anambra, Ebonyi, Enugu, and Imo. Probably, the zone is ethnically homogenous, being the heartland of the Igbo ethnic group. However, happenstances of recent times reveal that this zone is witnessing increasing rate of conflicts due to increasing nature of multi-ethnic character which the area is fast acquiring, particularly in urban areas such as Enugu, Onitsha, Owerri, and Aba. This pattern of conflict is not limited to urban areas. In the rural town of Ibagwa-Aka in Igbo-Eze South Local Government Area of Enugu State, there is a substantial population of Muslims of various ethnic origins including Nupe, Igala, Hausa, and Yoruba. Many years of inter-confessional marriages and conversions among the Christians, the Muslims, and the Traditionalists in Ibagwa have deepened this rare incidence of rural multiculturalism (Ibeanu and Onu, 2011: 1). Furthermore, a substantial proportion of the Igbo inhabitants of the community are Muslims, despite the predominant Christian religious affiliation of the Ndi Igbo. This unique case of rural multiculturalism has been explained as a product of historical interactions through trade and commerce between northern Igbos and the Igala (Afigbo, 1981: 90).

Arguably, the South-East Zone is almost ethnically homogenous. Conflicts in this zone have tended to be less inter-ethnic and more intra-ethnic. That is not to suggest that inter-ethnic conflicts between minority settlers and indigenous Igbo people in Ibagwa and between Igbos and Fulani herdsmen in villages and cattle markets should be ignored. However, sub-ethnic identity conflicts in the zone are numerous. These conflicts take their origins variously from dialects of the Igbo language, clans, administrative distrust and even towns. Although these sub-identities according to Ibeanu (2003: 169) often have cultural, linguistic and geographical origins; they are subsequently cultivated and nurtured 
politically. Consequently, the predominant basis for identify conflict in the area is sub-ethnic. Ibeanu (2003: 173) explains that the Wawa in the Enugu and Ebonyi states of the zone do not take the word 'wawa' to be more significant than its occurrence in many dialects in the area. Initially, it had no cultural connotation. However, careful cultivation of the identity by politicians from the area has raised it into a sub-ethnic identity treasured and accepted across the zone. This tendency to cultivate sub-ethnic identities, and to mobilize grievances behind them for political and economic purposes, especially the work of town and clan associations, have been very important in intra ethnic conflicts in the South-East Zone (Ibeanu, 2003).

The significance of the study of Ezza-Ezillo identity conflict is that first, it could serve as an experimental control for testing some assumptions underlying the study of ethnic conflicts in Nigeria, particularly those positing a link between ethnic differences and conflicts. Again, Ezza-Ezillo conflict focuses attention on intra-ethnic conflict which has not received adequate attention among scholars. This micro or sub-ethnic identity has not attracted much attention in the study of communal and ethnic conflicts in Nigeria.

\title{
2. Explaining Sub-Ethnic Conflicts
}

Identity-based conflicts became the dominant features of the historical, social and political processes in Nigeria from the late $1^{\text {th }}$ century to present day. Recent studies have pointed out the surge of rural ethnicity in Nigeria. Hitherto, ethnicity was formulated as a predominantly urban phenomenon (Ibeanu and Mbah, 2011: 3). Consequently, Nnoli (1980) posits that the colonial urban centre with its insecurities and uncertainties for the migrant was the cradle of ethnicity in Nigeria. In Nigeria today, identity conflicts are exacerbated by the growing poverty of ordinary Nigerians and the state's declining capacity for development. With the growing reduction in arable land due to a variety of reasons, land disputes keep multiplying especially in areas where communal boundaries are either too difficult to establish or contested by one of the parties. Consequently, identity conflicts due to social exclusion have increased the level of inter-communal violence and ethnic wars, which are defined here as cases of ethnic cleansing and genocide (Nzongola-Ntalaja, 2011:7).

Social exclusion is a function of class and other identity-based distinctions. The question of indigeneity in Africa assumes political significance with respect to identity- based conflicts in which the bone of contention is control over power and resources such as land. Inter-communal violence, based on identity conflicts, takes place between a group that defines itself as the rightful stakeholder and the one or those it perceives as intruders (Nzongola-Ntalaja, 2011: 8).

Ibeanu and Onu (2001: 3) have noted that the popularization of ethnicity in public discourse and academic research in Nigeria often conceal numerous unresolved theoretical and methodological issues surrounding identities and their roles in social and political action. They argued that these issues are crucial in any attempt to map ethnic and subethnic identities in Nigeria.

There are two contending perspectives in explaining ethnic and sub-ethnic identity conflicts in Nigeria. The first is the primordialists perspective. The primordial argument suggests the naturalness and/or innateness of ethnic or national identity (Stalin, 1942, Shils, 1957; Naroll, 1964; Otite, 1999). In this view, membership of an ethnic group is at least partly, biologically defined (Otite 1999: 19), which makes identities fixed (Stalin, 1942). Consequently, conflicts are inherent in inter-ethnic relations because ethnic groups have "ready made cleavages for man-made conflicts and alliances in a wider state system" (Otite, 1990:19).

This is what Horowitze (1998) calls the "hard view" on ethnic groups. In it, ethnic groups are:

\begin{abstract}
inscriptive, firmly bounded entities based on a strong sense of communality, producing considerable loyalty, persisting over time, providing large affective rewards to group members, inclined to ethnocentrism and hostility to and a desire to dominate outsiders, liable to conflict behaviour based on passion and engendering a great willingness on the part of group members to sacrifice for collective welfare.
\end{abstract}

There is a tendency for primordialists to confuse an individual's emotive subjectivity (feelings, consciousness, etc) towards an ethnic identity with its innateness. While it is true that certain biologically transmitted characteristics are necessary to make an individual's claim to the membership of certain identities plausible, it is not the case that such biological characteristics are adequate to define such identities (Ibeanu and Onu, 2001:3). The clearest example, according to them is race. It is assumed that the colour of one's skin may be necessary tickets for gaining access to a racial identity, but they are never sufficient conditions.

The second perspective is the constructionist perspective. This school of thought suggests that ethnic identities are not inherited like skin colour, but constructed like an art object (Laitin, 1998, cited in Ibeanu and Onu, 2011). Ethnic identity, like any other identity, is dynamic and fluid rather than fixed and bounded. People learn identities as they group 
and become exposed to family, community and national histories. Communal identity is, therefore, false consciousness.

However, while the view that these sentiments are natural is highly presumptuous and historical, the view that they constitute false consciousness, which is instrumentalized by ruling classes, is too voluntaristic to be fundamental (Ibeanu, 2003). Ake, (1985) attributes the persistence of ethnic consciousness in post-colonial Nigeria to what he calls 'the limited penetration of capitalism and commodity relations'. Consequently, he argues, that where there is a limited atomization of society, and the market ethic does not rule the lives of a vast majority of Nigerians in the rural areas. It is these factors which are characteristic of capitalism that can destroy such sentiments. Ake's formulation without doubt advances our understanding of the persistence of ethnic and other communal sentiments. But there are two major problems with his formulation. First is that in those areas of the formation where we could rightly say that capitalism has substantially penetrated, for example the urban areas, such sentiments remain quite strong. Second and more fundamental is that Ake describes only one form of capitalist commodity relations, namely, the free market/competitive type. While this may be conducive to the atomization of society and the growth of individualism, other forms of capitalist commodity relations such as monopoly and oligopoly may, in fact, hamper these processes.

Sub-ethnic conflicts have not featured significantly in the analysis of identity and citizenship in Nigeria. Most often the focus is on conflict among ethnic groups. However, adequate analysis of citizenship, particularly conflicts relating to indigeneity in Nigeria should properly document not only the inter-ethnic level but also the intra-ethnic level of the problem. All original legal definitions of citizenship in the world are notorious by their exclusionary character. The fundamental dimension of the notion of citizenship in Africa follows attachment to one's community and through it, to the soil of the ancestors or the homeland. This attachment was not in contradiction with the colonial legal concept of indigeneity, which was enforced through the indigenes, a separate legal status for Africans in French colonies until 1946 and the native authority system elsewhere.

The modern concept of citizenship is associated with the American and French revolutions. Citizenship became determined either by the place of birth (Jus soli or the law of the soil) or by blood (Jus Sanguinis). Consequently, while indigeneity or Jus Sanguinis is the first principle of citizenship in Africa, other legal principles do exist and can be used to broaden the boundaries of citizenship in post-colonial Africa (Nzongola, Ntalaja, 2011: 3). The democratization process, which involve expanding the political space to empower women, the young, ethnic minorities and other strata of the population, require the expansion of the boundaries of post-colonial citizenship beyond indigeneity in conformity with the realities and idea of globalization. However the poor performance of the federalist ideology in building a socially cohesive, politically stable and economically prosperous Nigeria is a result of weak commitment to the cultivation of "federal spirit" i.e. sufficient quantity of integrative principles and strict adherence to them in the process of governance.

At the heart of rural communal conflicts is the land question. Pressure on land resulting from a combination of expropriation, monetization, rising population density, degradation and resurgence of pre-colonial communal competition has raised land into a primal casus belli in rural communities. In this context, formal, modern demarcation of boundaries has ceased to be a trend. Consequently attempts by government to demarcate boundaries in order to keep warring communities apart, have failed to bring a lasting solution to violence (Ibeanu, 2003: 173).

Although land and the material interests are the objective causes of intra-ethnic conflict, they do not completely explain their persistence. There is a subjective dimension explaining their persistence. This is what we may describe as deep-seated animosity. By deep-seated animosity, we mean a sense of grievances shared by members of an intra-ethnic identity or a sustained sense of grievances towards another intra-ethnic identity arising from long standing conflict between the two. Consequently, while land is a necessary explanation of this conflict, it is this long standing animosity that explains their recurrence over time. This transformation is aptly demonstrated in the Ezza-Ezillo conflicts.

\section{Ezza-Ezillo Conflicts: The Interface of Material Interest and Animosity}

The two communities of Ezza and Ezillo are in Ishielu Local Government Area of Ebonyi State. They are believed to be homogenous in ethnic composition, marked out by a fairly distinct language, similar culture and a myth of common origin as well as having the same ancestral father with their kit and kin of Ngbo, Ezzamgbo, Izzi, and Ikwo communities of the state. Unlike many multi-ethnic communities in Nigeria, it was reasonable to assume that ethnic-based conflicts would be minimized in such a setting of ethnic homogeneity. However, this has not been so. Rather Ezza and Ezillo people have engaged themselves in a bloody battle contesting the ownership of Ishimkpume, Amalinze, and Umuezikoha land and this has assumed frightening dimension.

Consequently, one of the most important factors motivating conflicts among the Igbos is land. This is because of the spirituality of land in Igbo culture as expressed in the prominence of the deity Ana. It is also expressed in the general 
view that the land is the spiritual connector of the living, the dead and the unborn (Ibeanu and Mbah, 2011: 3). Thus, land is a very serious issue among the Igbo since it touches both the material and the spiritual, the very essence of Igbo ontology. Again, land is something that is worth dying for. However, the spiritual thesis affords a limited explanation of the violence that attends land disputes in Igbo land today. We think that at present the principal causal factors include the increasing commercialization of land, population pressure, collapse of traditional structures for gaining access to land and managing conflicts arising from it, as well as government rural development policies. Land remains one of the biggest basic natural resources in Igbo land. Land, however, is inelastic, yet population explosion is seriously making land acquisition, and compensation conflictive in nature and character.

While land and other material interests are the major immediate casus belli in communal conflicts they do not explain the identities that form around them and how these identities acquire specificity and become the basis of intensification of conflict. For instance, although both the Ezza and Ezillo agree that they are of the same ancestral father, their common descent has receded almost completely and they see themselves as distinct. It is paradoxical that two communities at one and the same time claim common descent, yet different identities. This paradox calls for an understanding or unpackaging of the character of identity formation and persistence. We can do this by reconciling the primordial/innate and constructions/instrumentalist viewpoints. The two are not opposing but they are dimensions of a historical process of emergence and development of ethnic and sub-ethnic identities. To be sure, an ethnic identity exists where there is a large group of people defined by:

1. Their collective consciousness of belonging to a cultural, linguistic or other communal ensemble;

2. Their collective attachment to a specific geographical homeland, and

3. Their collective engagement in the propagation and transmission of that identity over a relatively long period of time (Ibeanu and Mbah, 2011: 5).

However, the Ezza-Ezillo conflict started as a resource conflict over material interest in Ishimkpume, Amalinze, and Umuezikoha lands, and is now an animosity conflict. An animosity conflict is one in which memories of past conflicts acquire a relative autonomy, and become significant in renewing and intensifying conflicts. Animosity conflicts are likely to be prolonged conflicts in which the protagonists have memories of loss, hurt or humiliation. An animosity conflict often begins as resource conflict. However, over time the original cause of the conflict becomes only apparent, while bitter memories become the immediate course of new conflict. At the same time, fears of preemptory attacks by the opposing side usually provide a very short fuse that ignites new round of conflict.

\section{An Analysis of the 2008 and 2010 Ezza-Ezillo Conflict}

In Nigeria, the differential access, ownership, and control of land (farming, fishing, grazing, oil deposit, solid mineral deposit, etc.) by the nationals and the government is largely responsible for the recurrent incidents of sub-ethnic or intercommunal hostilities in the country. Ebonyi State is essentially dominated by peasant agricultural based communities. Instances of inter-communal strife are not alien to the state; it has witnessed pockets of sub-ethnic identity conflicts even before its creation in 1996. These fratricidal internecine conflicts (most of which have been resolved) include the communal conflict between Mgbalukwu, Obeagu, and Ojiegbe communities in Onicha Local Government Area; AkaezeOso Edda Land Dispute in Afikpo South Local Government Area; Nwanu-Nduoffia Communal Clashes in Izzi Local Government Area; ABC Farm Settlement Crisis in Ikwo Local Government Area; Crisis in Ameka Community over the ownership of Ameka Mining Corporation in Ezza South Local Government Area; Edukwuachi-Agbaja Communal Conflict in Izzi Local Government Area (Ebonyi State Department of Border Security and Conflict Resolution Report, 2011).

The inter-communal interaction between the people of Ezillo and Ezza dates back to the late 1920s. The Ezillo Community, now the headquarters of Ishielu Local Government Area, had a communal conflict with Ngbo, its neighbouring community in the present-day Ohaukwu Local Government Area of the state. Because of their apparent ethnic homogeneity and myth of common descent which invariably forbade the Ezillo Community from shedding the blood of Ngbo people, Ezillo decided to lay a complaint before Ezza, generally regarded as the oldest of all Abakaliki clans. Accordingly, the Ezza came to make peace between the Ezillo and Ngbo Communities by occupying the buffer territory, which Ezillo insists is in the present-day Eguechara. On the contrary, the Ezza version of the story indicates that they were invited to fight and drive the Ngbo backwards and live in the land which is now the claimed present-daydisputed areas of Ishimkpume, Amalinze, Umuezikoha, amongst other hamlets in dispute.

The two communities had lived together peacefully and had even been inter-marrying after the defeat of Ngbo. Ezza people are generally nomadic, most populous, and most evenly spread across the three geo-political zones of the state. They are also found in Wawa land in Enugu as well as some parts of Benue, Kogi, and Cross-River States. 
Wherever the Ezza occupied, they would build new settlements and name such a place after themselves, hence there are places like Ezza-Ezillo, Ezza-Effium, Ezza-Akpoga, etc (Agbo, 2010:1; http://www.newswatchngr.com 13/02/2012). However, for purposes of this study, we shall consistently employ Ezza instead of Ezza-Ezillo in reference to the Ezza community of Ezillo extraction.

The Ezillo Community further holds that only twenty two Ezza men were invited to come and settle in Ezillo originally. With passage of time, however, they (the Ezzas) started inviting their kit and kin from Onueke, in the presentday Ezza South Local Government Area and began to occupy the extra portions of land that made both the Ezillo and Ezza live without a clearly defined boundary. Consequently, problems ensued and Ezillo sought for Ezza relocation to Eguechara, the place the former maintained was the original place it agreed to give to the latter. The matter was taken to an Abakaliki colonial customary court in 1955 and the court ruled in favour of Ezillo, thereby mandating the Ezza to move to Eguechara.

The Ezza appealed the matter before an Abakaliki colonial district officer called Mr. Gunning who affirmed the judgement of the customary court. However, the Ezza remained in the land till gth May, 2008, when the dispute that led to the February 19, 2010 and December 31, 2011 recrudescence of bloodbath in the area started.

Although land has been identified as the primal casus belli in the origination and escalation of the protracted conflict, the Ezzas' quest for different identity is also implicated in its recrudescence. They had built churches and separate traditional leadership institutions for themselves as a means of checkmating the dominance of the Ezillo people who regarded them as settlers. For many years the Ezillo Community had complained that scholarships meant for their indigenes were taken by the Ezza people because of their positions in government both at the state and federal levels. That is why Otite (1999: 25) argues that identity mobilization acquires significance because of the struggle for access to a variety of limited resources which could include power, chieftaincy, market or land. More often than not the negative mobilization of such identities as ethnicity, religion, language, clan or race in the pursuit of access to the limited resources further fuels conflict and violence. The Ezillo people began to see the position of the Ezzas as a threat and consequently mobilized themselves to checkmate their hegemonic disposition.

The latest war started after a misunderstanding on where to erect a commercial pay phone booth broke out between an indigene of Ezillo and an Ezza man. The disagreement led to the pulling down of the booth and consequent burning of motorcycles that belonged to both parties. The problem escalated and culminated into a full-blown war with the attendant loss of innocent lives and destruction of valuable property. Although, it was settled, it resurfaced with a much greater force in January 2010, leaving hundreds of residents, unsuspecting travellers and police officers dead. The recent crisis between Ezillo and Ezza communities dubbed 'The Ezillo Mass Murder' cropped up on December 31, 2011. According to Ubabukoh (2012:1), when relative peace eventually returned, over 70 people were dead, over 100 survivors are still recuperating in various hospitals in the state while about 700 people were declared missing. Essentially, the war was a hangover or reverberation of the deep-seated animosity between the two belligerent communities which was often suppressed by recourse to the coercive apparatuses of the state.

\section{Previous Attempts to Manage the Conflict}

As stated earlier, the efforts of the government to address the internecine conflict between the Ezillo and Ezza communities dates back to the colonial era. The matter was brought to an Abakaliki colonial customary court in 1955 when the court ruled in favour of Ezillo, mandating the Ezza to move to Eguechara. However, the Ezza appealed the matter before an Abakaliki colonial district master, Mr. Gunning who affirmed the judgment of the customary court. However, the Ezza remained in the disputed territories till May 2008 when the inter-communal conflict became full-blown.

Consequently, the Ebonyi State Government set up a peace committee headed by Eze Chibueze Agbo, the traditional ruler of Ezzamgbo, with the mandate to unravel the remote and the immediate causes of the conflict and make recommendations accordingly. The formation of the committee was vehemently opposed by Ezza people, especially concerning the objectivity of its headship. The Ezza community accused Governor Martins Elechi of composing a panel headed by an Ngbo man, who could carry over the grudge of the Ezza's olden days' war against the Ngbo. Thus, the Ezza expressed their loss of confidence in the panel that was sitting in Ishielu Local Government Council Secretariat instead of the preferred state capital.

The committee amongst other things recommended the relocation of Ezza to Eguechara land originally allocated to them by Ezillo people through the customary method of land allocation imaba ogbu. The Government White Paper of $2^{\text {nd }}$ October, 2008 on the panel report accepted the report and consequently directed the Ezza to vacate a substantial portion of the land to Eguechara (Mkpuma, 2012:3). The Ezza protested that they had been short-changed and swore 
never to relocate to the new land; leaving their houses and cash crops.

With the withdrawal of the military in 2010, the then Inspector General of Police, Ogbonnaya Onovo, ordered a large scale police operation in the area to flush out militants who were killing innocent users of Abakaliki-Enugu expressway at will. According to Mkpuma (2012:3) a combined team of men of the Ebonyi State Police command and those of the Force Headquarters, Abuja, stormed six enclaves of the warring militants, capturing 34 persons, including women. He further noted that the operation witnessed the deployment of police helicopter and over 1500 mobile policemen from various mobile units across the country. The police sacked the remaining Ezza people from the disputed area and forced them to relocate to Ezza North Local Government Area (their ancestral home). However, the operation witnessed a huge casualty with more than 400 lives lost, including those of 16 policemen and three soldiers in the Abakaliki-Enugu Expressway (Mkpuma, 2012:4). The exercise led to the suppression of the communal unrest until the December 31, 2011 attacks that reopened the old wounds.

\section{Policy Option and Conclusion}

True conflict resolution requires a more analytical, problem-solving approach than dispute settlement. The main difference is that resolution requires identifying the causal factors behind the conflict, and finding ways to deal with them. On the other hand, settlement is simply aimed at ending a dispute as quickly and amicably as possible. This means that most sub-ethnic conflicts are settled, while, the underlying causes of the conflicts are not addressed.

The heights of serious conflicts in Nigeria are attained following the dispatch of soldiers to quell crisis, and this has become a regular method of settlement in most communal conflicts in Nigeria. This method sees that fighting between the communities involved is stopped. However, the underlying causes of the conflict structure of society are not usually addressed. No significant socio-economic or political changes that restructure the boundaries or economic welfare in a more just or inclusive way are adopted by the government. As a result, there are reoccurrence of sub-ethnic identity conflicts in Nigeria. Thus, conciliation is sacrificed. We therefore recommend conciliation as a major strategy for the purpose of resolving Ezza-Ezillo conflict. Conciliation is a process whereby Ezza and Ezillo communities would agree to utilize the services of a conciliator or conciliators who meet with the leaders of the communities involved in an attempt to resolve their differences. Through this process, concessions are sought and reached. When this is achieved, understanding between the communities will also be achieved.

The conflicts between Ezza and Ezillo show that citizenship question is below the often issue of ethnic question. The reason is that intra-ethnic conflicts demonstrate the interface and the centrality of material questions in defining citizenship conflicts. Ibeanu and Mbah (2011: 14) explain that indigenes and settlers are contrary to common reasoning, principally economic categories. This is to understand the intricate ways in which economic interest become part of the complex of construction, propagation, primordializaion and intensification of contradictory cultural identities, leading to indigene-settler conflicts. The pieces of land namely Ishimkpume, Amalinze, and Umuezikoha, are the central cause of the Ezza-Ezillo conflict. While the ownership of the disputed territories is the lasting cause of the conflict, the animosity arising from a lingering sense of deprivation has assured its persistence. It is in the context of this animosity that Ishimkpume land amongst others has become a central basis for contracting, propagating, primodializing and intensifying the differences between the two communities. It is difficult to reverse this trend and pattern of conflict between Ezza and Ezillo.

As Ibeanu (2003) notes, regarding the Aguleri-Umuleri conflicts, the zero-sum solutions that have been predominantly pursued by the state since colonial times have not, in any way, helped matters in resolving the microethnic conflicts. Both in court judgments and in white papers of investigation panels, these solutions have applied standards of justice which only serve to exclude people and deepen animosities. Consequently, alternative solutions to Ezza-Ezillo conflicts need to be sought since the zero-sum solutions have failed to bring peace to the two communities. We think the Aguleri-Umuleri solution might also be helpful.

The major thrust of this initiative was the return to traditional means of settling disputes. The settlements of the Aguleri-Umuleri conflict started by setting up a process of traditional oath taking and covenant to end the feuding and shedding of blood. Oath taking (inu iyi) and blood covenant (Iko Mme or Igba Ndu) are common traditional practices in traditional societies of the Igbo people. The first involve swearing to powerful community deities and pledging a specified course of behaviour. Oath-taking was a very powerful mechanism for behavioural change in traditional Igbo societies. The second arises in situations where there has been shedding of blood. It is a means of appeasing the Ana deity, who abhors the spilling of blood (Ibeanu and Mbah, 2011: 15). Igba ndu involves sacrifices and may also involve reparations taking the form of exchange of human beings to replace the dead or mere exchange of valuables and/or services. These 
practices which had previously been widely abandoned were reinvented in spite of the tremendous progress of Christianity in the case of Aguleri-Umuleri area. Those practices helped to bring peace to the two communities. This signifies the failure of previous approaches to solving the problem. These practices can be applied in the case of EzzaEzillo conflicts as a mechanism for peace and stability in the two communities and their environs. This would follow after the first one, conciliation has been reached.

\section{References}

Afigbo, A. (1981). Ropes of Sand: Studies in Igbo History and Culture. Nsukka: UNN Press.

Agbo, D. (2010). Brothers at War: The Story of the Ezza-Ezillo Communal Strife. Retrieved from http://www.vanguardngr.com /2010/03/brothers-at-war-the-story-of-the-ezzaezillo-communal-strife/ on 11 $1^{\text {th }}$ May, 2013.

Ake, C. (1985). The Future of the State in Africa. International Political Science Review, Vol. 6 No. 1.

Easterly, W. and Levine, R. (1997). Africa's Growth Tragedy: Policies and Ethnic Division. Quarterly Journal of Economics, 112 (4): $1203-50$.

Frank, R. and Rainer, I. (2012). Does the Leader's Ethnicity Matter? Ethnic Faviouritism, Education and Health in Sub-Saharan Africa. American Political Science Review, 106(2): 294-325.

Ibeanu, O. and Onu, G. (2001). Ethnic Groups and Conflicts in Nigeria (Vo.2): The Southeast Zone of Nigeria: Programme on Ethnic and Federal States.

Ibeanu, O. (2003). Aguleri-Umuleri Conflict in Anambra State. In T. Imobighe (ed.), Civil Society and Ethnic Conflict Management in Nigeria. Ibadan: Spectrum Books Limited.

Ibeanu, O. and Mbah, P. (2011). Sub-Ethnic Identity and Conflict in Nigeria: Revisiting the Aguleri-Umuleri Conflict in Anambra State. Paper presented at the National Workshop on Citizenship and Indigeneity Conflicts in Nigeria organized by the Centre for Democracy and Development held at Denis Hotels, Abuja from $8^{\text {th }}$ to $9^{\text {th }}$ February.

Imobighe, T. (2003). Ethnicity and Ethnic Conflicts in Nigeria: An Overview. In T. Imobighe (ed.), Civil Society and Ethnic Conflict Management in Nigeria. Ibadan: Spectrum Books Limited.

Mkpuma, B. (2012). Ezza-Ezillo Crisis: Matters Arising. Retrieved from http://www.newsdiaryonline.com/ezza-ezillo-crisis-mattersarising-by-be - 86k - on 11 th May, 2013.

Naroll, R. (1964). "On Ethnic Unit Classification" Current Anthropology, Vol. 5 No. 4 (October).

Nnoli, O. (1980). Ethnic Politics in Nigeria, Enugu: Fourth Dimension Publishers.

Nzongola-Ntalaja, G. (2011). Citizenship and Exclusion in Africa: The Indigeneity Question. A paper Presented at the National Workshop on Citizenship and Indigeneity Conflicts in Nigeria organized by the Centre for Democracy and Development, Abuja, Nigeria February 7-9.

Otite, O. (1990). Ethnic Pluralism and Ethnicity in Nigeria, Ibadan: Shaneson.

Report of the Ebonyi State Department of Border Security and Conflict Resolution (2011). Retrieved from http://www.ebonyionline.com Izzz-ebonyi-sta... on $11^{\text {th }}$ May, 2013.

Shils, E. (1957). Primordial, Personal, Sacred, and Civil Ties. British Journal of Sociology, vol. 8 (June). Pp. 130-45.

Stalin, J. (1942). Marxism and the National Question. New York: International Publishers.

Ubabukoh, O. (2012) Ezillo: Children, Youths Still Drenched in Tears. Retrieved from http://www.punchng.com/feature/ezillo-childrenyouths-still-drenche - 73k on 11 May, 2013. 